International Journal of English Literature and Social Sciences
Vol-6, Issue-2; Mar-Apr, 2021

\title{
The mediation role of change management in employee development
}

\author{
Bayad Jamal Ali ${ }^{1}$, Govand Anwar ${ }^{2}$
}

\begin{abstract}
${ }^{1}$ Business Administration Department, Komar University of Science and Technology, Sulaimani 46001, Kurdistan Region - Iraq ${ }^{2}$ Department of Business Administration, College of Administration and Financial Sciences, Knowledge University, 44001 Erbil, Kurdistan Region, Iraq
\end{abstract}

Received: 03 Jan 2021; Received in revised form: 10 Mar 2021; Accepted: 26 Mar 2021; Available online: 27 Apr 2021 (C2021 The Author(s). Published by Infogain Publication. This is an open access article under the CC BY license (https://creativecommons.org/licenses/by/4.0/).

\begin{abstract}
In an increasing number of hotels, hospitality is being used to improve productivity and care quality. The research was conducted in the hospitality industry, specifically in private hotels in Sulaimaniah. The study looked at the perspective of change management in the hospitality industry, specifically in private hotels. However, due to an implementation difference: the gap between plan and execution, the hospitality industry has difficulty implementing reform initiatives. The aim of this paper, from a change management standpoint, is to increase scientific knowledge about factors that reduce the implementation gap and facilitate the transition from "toolbox lean" to real lean hospitality transformation. To find a change management perspective in the hospitality industry, the researchers used a quantitative analysis approach. A total of 90 administrative staff members from private hotels were given the questionnaire at random. The participants in this study were 76 people from various private hotels in Iraq's Kurdistan province. The researchers used multiple regression analysis to assess their established research hypotheses, while the Sobel test was used to determine the function of the mediator, which is the change management initiative. The results showed that all research hypotheses are supported, with the third research hypothesis receiving the highest value, stating that change event mediates education and strategic success, and the first research hypothesis receiving the lowest value, stating that change event mediates technology change and strategic success. Furthermore, it was discovered that change eventplay a constructive and significant role in bridging the gap between change management and strategic performance.
\end{abstract}

Keywords-Employee Development, change management, hospitality, Kurdistan-Iraq.

\section{INTRODUCTION}

Over the last few decades, there has been a growing awareness of the need for hospitality organizations to change and strengthen. Tighter budgets, fluctuating financial markets, central government decisions, safety regulations, regulation, and information technology, as well as more turbulent conditions, prompted hospitality organizations to introduce and incorporate improvements in the governance, structure, architecture, and quality of services offered to people after the 19th century (Neves et al. 2018). Several governments around the world have initiated reforms and innovations that have altered the governance of hospitality bodies in both developed and developing countries. The traditional hospitality model, which dominated most of the twentieth century, has changed to a more flexible, market-based form of hospitality since the mid-1990s (Ali, 2020). A modern model of hospitality governance emerged in both developed and developing countries by the end of the 1980s and the beginning of the 1900s. Although the current governance model for the hospitality industry has been referred to by a number of terms, such as 'fresh hospitality-NPM' (Luburić, 2019); 'post-bureaucratic paradigm' (Serugga et al., 2020); 'entrepreneurial democracy' (Anwar, 2017); or'managerialism' (Hurtt et al. 2020), they all refer to the same phenomenon. That is, continued modernisation, development in hospitality, cost-cutting, privatization, and marketing of hospitality businesses. In other words, several 
governments around the world have implemented hospitalitygovernance reforms to improve the quality and effectiveness of hospitalitygoods and services (Hameed \& Anwar, 2018), as well as to make hospitalityorganizations more adaptable and resilient to an evolving environment similar to that of others.

Hospitality management reform is described as a concerted attempt by political and senior management to alter structural, technological, or process features of "hospitalityorganizations in order to make them (in some sense) better controlled" (Ali, 2021). To date, the transformation of the hospitality industry has been studied from a number of theoretical viewpoints, all of which are similar. For example, Andavar \& Ali (2020) looked at the transformation of the hospitality industry from an administrative standpoint, which is thought to be one of the most popular perspectives in the industry.

The restructuring of government. Improvement and adaptation are imposed by the external background of organizations, according to institutional researchers, rather than deliberately initiating and implementing improvements and modifications to maximize efficiency and effectiveness (Anwar \& Shukur, 2015). Other analysts have looked at the transformation of the hospitality industry from a practical standpoint. According to the instrumental perspective on transition, hospitality institutions serve as instruments for elected officials and senior executives (Anwar, 2017). This point of view is primarily concerned with improvements in the institutional characteristics of hospitality establishments. In addition, elected leaders of hospitality organizations identify and express the goals and objectives of the change and development process. Business leaders believe that the effective implementation of new policies and transformation plans "will be dependent on government control of what happens to programs and initiatives" (Neves et al. 2018). While these different perspectives provide specific perspectives on reform and development in the hospitality industry, they all focus on national or sectorlevel reform and improvement. To put it another way, none of these perspectives offers insight into how change is implemented and managed within a single governmental body. Change management is a viewpoint that highlights the dynamics of transition and organizational transformation (Anwar \& Ghafoor, 2017). While elected or publicly appointed politicians and administrators often institute new policies and programs, the real changes in hospitality institutions are enforced by middle- and first-line management as well as front-line workers. According to the change management perspective, the reform design can and should be separated from the change implementation; after those in charge of reform design the reform, the task of executing or translating the reform should be turned over to those who are capable of doing so in the most realistic and efficient way possible (Demir et al. 2020). In other words, after political and senior management have endorsed the change, it is up to staff at the middle and lower levels of management to implement it. As a result, change is described as what is occurring in the structural, technological, or process of hospitality organizations, as well as employee attitudes and behavior (Anwar \& Shukur, 2015). To put it another way, it is a means of implementing reforms initiated by political and senior executive officials by lower-level managers and civil servants who are transition beneficiaries. Political and senior administrative officials will continue to place pressure on hospitality organizations to make improvements, but if middle managers and lower-level hospitality employees (change recipients) are unable to implement these reforms, the chances of failure are high (Ali, 2021). It's also important to note that not all changes result in actual improvements in the hospitality industry. In some cases, decision-makers' plans seem to be constructive at first glance; but, since hospitality bodies are reluctant to implement them, the improvements are not implemented and the measures remain on paper (Anwar \& Balcioglu, 2016). It's also worth remembering that the changes are broad in scope and are usually orchestrated by political and administrative leaders through a major political process (Jones-Schenk, 2019). Change management, on the other hand, is concerned with the internal administration and implementation of structural change or restructuring. In this article, I focus on single hospitality organizations' internal change management processes rather than reforms at the national or sector level. In other words, the issue addressed in this dissertation is how recipients of change perceive the changes undertaken by senior hospitality executives in a single hospitality establishment, as well as the conditions under which recipients of change react favorably and, if possible, proactively to these organizational change efforts. The reason for concentrating my attention on change recipients' responses is that the effectiveness of every transformation or enhancement effort is highly reliant on change recipients' attitudes and ability to effectively design, schedule, and implement organizational change (Anwar, 2017).

\section{Research Model}


Change Management Elements

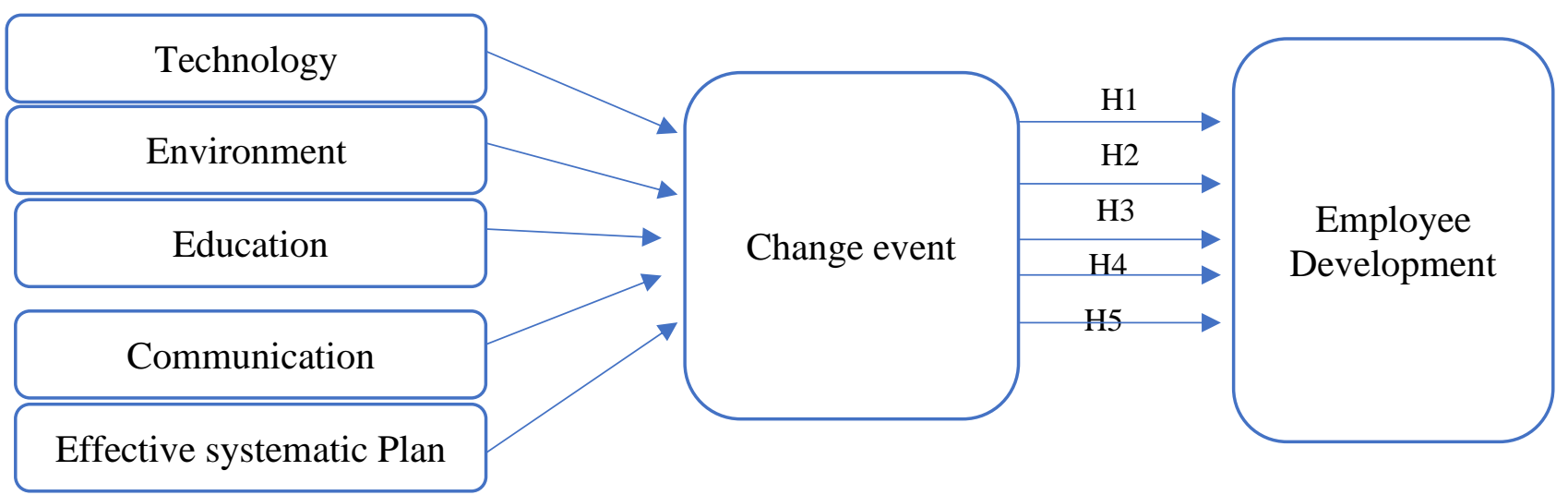

\section{Research Hypotheses:}

H1: Change event mediates technology change and Strategic success.

$\mathrm{H} 2$ : Change event mediates environment of the change and Strategic success.

H3: Change event mediates education and Strategic success.

H4: Change event mediates communication and Strategic success.

H5: Change event mediates effective systematic plan and Strategic success.

\section{THEORETICAL BACKGROUND}

Shift beneficiaries are not robots, according to change management theory; they are simply carrying out changes imposed from on high by policymakers. Rather, this viewpoint implies that change recipients are knowledgeable, that they are aware of the issues that their organizations are tasked with solving, that they have valuable ideas for solving those problems, and that, given the chance, they can easily convert those ideas into meaningful action (Kirrane et al. 2017). The beneficiaries of change are (Anwar \& Abd Zebari, 2015) encouraged to engage in the decision-making process under the change management model. According to the change management view, nothing can change without the involvement of change recipients (Anwar \& Qadir, 2017). In other words, according to the change management viewpoint, reform and change programs must "ultimately result in improvements in the operating processes of hospitality organizations, as well as in the attitudes and actions of workers working in those organizations" in order to have some effect (Anwar \& Surarchith, 2015). Organizational participants are required to act, act, and conduct their duties differently as a result of the restructuring and change of initiatives. Employees are expected to leave their comfort zones as a result of organizational changes (Hussain et al. 2018), and they are expected to abandon old habits and systems in favor of new ones that are aligned with the change effort's task (Abdullah et al. 2017). Anwar (2017) argues that "if people do not improve, there will be no organizational change" (Goksoy,
2020) and that "change only persists over time when individuals change their on-the-job actions in an acceptable manner" (Ali, 2021). Others claim that "organizations cannot improve meaningfully until workers changepeople must think, believe, and act differently" (Ali, 2020). Employee attitudes and actions toward organizational change activities, among other variables, can thus be argued to be one of the key determinants of performance and efficacy of most organizational change efforts. Researchers and practitioners have established a variety of factors that are suggested to affect the reaction of change recipients to organizational change proposals after Kurt Lewin's early work on organizational reform in the 1940s. Anwar, (2016) summarized and analyzed the literature on organizational change and development, which was a critical step toward the theoretical synthesis of the literature on organizational change management variables. On the basis of a broad literature review, their study provided a framework for the classification of organizational change variables. Their classification system divides actionable change management variables into four categories: material change, method, context, and criterion or outcomes. Person attributes were added to the organizational change process by Hameed \& Anwar, (2018) in another report. Ali, (2020) applied leadership to the taxonomy in a more recent review of the literature on hospitality change management. The classification of organizational change management variables allows for the identification of predictors of the psychological processes that cause change beneficiaries' 
behaviors to change (Anwar \& Ghafoor, 2017). This taxonomy has gotten a lot of attention from analysts and administrators in recent years, and it has found methodological support in a number of countries, both in the hospitality and private sectors (Anwar, 2017). The importance of the parameter variables regularly evaluated as the outcomes of organizational change programs is one of the research topics reviewed by Serugga et al. (2020). In the hospitality industry, it is proposed that government officials and senior executive leaders of hospitality organizations often express reform and transformation goals in ambiguous or even contradictory language, making it difficult to decide whether or not the outcomes are compatible with the intended outcomes (Hameed \& Anwar, 2018). As a result, before determining proof of outcomes, it is essential to define what is considered an outcome (Ali, 2021). The term "effect" can be applied to a variety of situations and can include a wide range of meanings (Andavar \& Ali, 2020). Furthermore, philosophers and clinicians differentiate between a narrow and a wide concept of outcomes. The narrow concept of outcomes emphasizes anticipated or expected outcomes, such as success, quality, and productivity (Lu et al. 2020). When evaluating narrow performance, whether the enhancement and transformation programs' targets are translated into decisions and outputs is considered. The expanded concept of outcomes, on the other hand, is concerned with dysfunctions, side effects, and political and social effects, "such as those resulting from socio-democratic leadership" (Anwar, 2017). The approach for evaluating the outcomes of change programs differs depending on whether the change is anticipated or unexpected. Organizational change is viewed as a process that moves an institution from an undesirable, current, fixed state to an ideal future state through a series of pre-defined phases in the planned approach to transition (Anwar \& Climis, 2017). The priorities of transition are formulated at the start of the change process in this top-down approach to transformation, which heavily relies on management's effect on its implementation (Anwar \& Ghafoor, 2017). Change usually begins with an examination of the current unfavorable situation and the development of an ideal future state (Demir et al. 2020). In preparation for the proposed reform approaches, the results are also scheduled (Anwar \& Shukur, 2015). Transition effects, on the other hand, are not currently implemented in the evolving reform plan, but rather arise during the change phase as the change itself occurs (Anwar \& Louis, 2017). Since the transition's priorities and expected outcomes aren't known ahead of time, predicting the outcomes of the change in the emerging approach to change is more challenging. Improved performance (Anwar \& Balcioglu, 2016), efficiency (Ali \&
Anwar, $2021 \&$ Anwar, 2017), customer loyalty (Ham et al. 2020), equity and security (Anwar \& Qadir, 2017), increased performance, or "increase in the total capacity/flexibility/resilience of the administrative structure as a whole" (Baporikar \& Kaloia, 2020). Some researchers have taken a more objective approach to evaluating the effects of modification on output shifts. For example, Bivona \& Cosenz (2021) calculated the number of applicants for a new hospital charitable care scheme to determine the outcomes of the reform program. As previously stated, long-term organizational transition is primarily dependent on positive perceptions and behavioral support for planned employee change activities. In other words, how change recipients respond to change attempts is one of the most important determinants of the degree to which any organizational transformation can succeed. Despite this early interest in the role of transfer recipients' attitudes in the process of organizational change, researchers and practitioners did not pay attention to organizational change until the late 1940s. Indeed, there has been a surge in organizational transformation research in the last 70 years, highlighting the importance of employees' attitudes and behaviors in understanding change initiatives (Abdullah et al. 2017). Behaviors have been conceptualized through a number of contexts in the literature on organizational change, with little consistency in their definitions or the terms used. According to the literature review, various terms or terminology are used to explain the same phenomenon at times, and the same word is used for structures with different meanings at other times (Anwar, 2017). Despite the disintegration and muddled manifestations of employee attitudes toward change, they defined seven recurring constructs: (1) resistance to change, (2) skepticism about organizational change, (3) commitment to change, and (4) openness to change. "All reflect an individual's overall positive or negative view of a specific change program," according to the first six attitudinal frameworks (Goksoy, 2020). Despite similarities, there are a number of significant differences in terms of ramifications and focus between them, and as a result, researchers and clinicians can provide varying evidence of employee evaluation and concerns about individual reform initiatives. The seven outcome variables mentioned above can be divided into three classes based on how they respond to change. The first, and most likely the first form. One consists of negative answers and suggestions regarding transformation situations, such as resistance to change (Abdullah \& Anwar, 2021 ) or cynicism toward change (Bae, 2020). ( $\mathrm{Li} \& \mathrm{Hu}, 2020$ ). More optimistic responses, such as tolerance for change, desire to improve, willingness to adjust, and commitment to change, are 
included in the second category of outcome factors (Abdullah et al. 2017).

\section{METHODOLOGY}

The research was conducted in the hospitality industry, specifically in private hotels in Sulaimaniah. The study looked at the perspective of change management in the hospitality industry, specifically in private hotels. To assess hospitality's strategic success, the researchers used five change management dimensions, such as technological change, change climate, and strategic success, education, communication, and an effective systematic strategy. Furthermore, the researcher used change eventas a mediator between all five independent variables in order to assess the competitive performance of hospitality businesses. To find a change management perspective in the hospitality industry, the researchers used a quantitative analysis approach. A total of 90 administrative staff members from private hotels were given the questionnaire at random. The participants in this study were 76 people from various private hotels in Iraq's Kurdistan province. The questionnaire contained 59 things ranging from $1=$ Strongly Disagree, 2= Disagree, 3= Neutral, 4= Agree, and 5= Strongly Agree, all of which were measured using a fivepoint Likert scale ranging from 1=Strongly Disagree, $2=$ Disagree, 3= Neutral, 4= Agree, and 5= Strongly Agree.

\section{ANALYSIS AND RESULTS}

Table 1- KMO and Bartlett Sphericity Test of Self-rating Items

\begin{tabular}{|c|c|c|c|c|c|}
\hline \multirow[t]{2}{*}{ Factors } & \multirow[t]{2}{*}{$\mathrm{N}$ of items } & \multirow[t]{2}{*}{$\mathrm{n}$} & \multirow[t]{2}{*}{ KMO } & \multicolumn{2}{|c|}{ Bartlett test } \\
\hline & & & & Chi-Square & Sig \\
\hline Technology Change & 8 & 76 & \multirow{7}{*}{.751} & \multirow{7}{*}{2155.2} & \multirow{7}{*}{.000} \\
\hline Environment of the Change & 9 & 76 & & & \\
\hline Education & 8 & 76 & & & \\
\hline Communication & 8 & 76 & & & \\
\hline Effective systematic plan & 9 & 76 & & & \\
\hline Strategic success & 9 & 76 & & & \\
\hline Change Management & 8 & 76 & & & \\
\hline
\end{tabular}

As we can see in table (1), the result of KMO for all five independent variables (technology change, environment of the change, education, communication, and effective systematic plan), and Strategic success as dependent variable also change management as mediator factor; is .751 which is higher than .001 this indicates that the sample size used for the current study was more than adequate. Furthermore, the result of Chi-Square is 2155.2 with the significant level .000.

Table 2: Reliability analysis

\begin{tabular}{|c|c|c|c|}
\hline Variables & N of items & $\mathrm{n}$ & Cronbach's Alpha \\
\hline Technology change & 8 & 76 & .733 \\
\hline Environment of the Change & 9 & 76 & .768 \\
\hline Education & 8 & 76 & .791 \\
\hline Communication & 8 & 76 & .774 \\
\hline Effective systematic plan & 9 & 76 & .739 \\
\hline Employee development & 8 & 76 & \\
\hline Change Management & & & 76 \\
\hline
\end{tabular}

As seen in table (2), the reliability analysis for 59 items used to measure the influence of five independent variables (technology change, environment of the change, education, communication, and effective systematic plan), and Strategic success as dependent variable also change management as mediator factor. The above 59 questions 
were distributed as follow; 8 items for Technology change, 9 items for Environment of the Change, 8 items for Education, 8 items for Communication, 9 items for Effective systematic plan, 9 items for Employee development, and items for 8 items for change management. The researchers applied reliability analysis to find out the reliability for each factor, the findings revealed as follow: as for Technology change was found the Alpha to be .733 with the sample size of 76 for 8 questions which indicated that all 8 questions used to measure Technology change were reliable for the current study, as for Environment of the Change was found the Alpha to be .729 with the sample size of 76 for 9 questions which indicated that all 9 questions used to measure Environment of the Change were reliable for the current study, as for Education was found the Alpha to be .768 with the sample size of 76 for 8 questions which indicated that all 8 questions used to measure Education were reliable for the current study, as for Communication was found the Alpha to be .791 with the sample size of 76 for 9 questions which indicated that all 9 questions used to measure Communication were reliable for the current study, as for Effective systematic plan was found the Alpha to be .788 with the sample size of 76 for 9 questions which indicated that all 9 questions used to measure Effective systematic plan were reliable for the current study, as for Employee development was found the Alpha to be .774 with the sample size of 76 for 9 questions which indicated that all 9 questions used to measure Employee development were reliable for the current study, and as for Change Management was found the Alpha to be .739 with the sample size of 76 for 8 questions which indicated that all 8 questions used to measure Change Management were reliable for the current study.

Table 3: Correlation Analysis

\begin{tabular}{|c|c|c|c|c|c|c|c|}
\hline \multicolumn{8}{|c|}{ Correlations } \\
\hline & & $\begin{array}{l}\text { technology } \\
\text { change }\end{array}$ & $\begin{array}{l}\text { environment } \\
\text { of the } \\
\text { change }\end{array}$ & education & communication & $\begin{array}{l}\text { effective } \\
\text { systematic } \\
\text { plan }\end{array}$ & $\begin{array}{l}\text { Strategic } \\
\text { success }\end{array}$ \\
\hline \multirow[t]{3}{*}{$\begin{array}{l}\text { technology } \\
\text { change }\end{array}$} & $\begin{array}{l}\text { Pearson } \\
\text { Correlation }\end{array}$ & 1 & & & & & \\
\hline & Sig. (2-tailed) & & & & & & \\
\hline & $\mathrm{N}$ & 76 & & & & & \\
\hline \multirow[t]{3}{*}{$\begin{array}{l}\text { environment of } \\
\text { the change }\end{array}$} & $\begin{array}{l}\text { Pearson } \\
\text { Correlation }\end{array}$ & $.544^{* *}$ & 1 & & & & \\
\hline & Sig. (2-tailed) & .002 & & & & & \\
\hline & $\mathrm{N}$ & 76 & 76 & & & & \\
\hline \multirow[t]{3}{*}{ education } & $\begin{array}{l}\text { Pearson } \\
\text { Correlation }\end{array}$ & $.601^{* *}$ & $.638^{* *}$ & 1 & & & \\
\hline & Sig. (2-tailed) & .000 & .000 & & & & \\
\hline & $\mathrm{N}$ & 76 & 76 & 76 & & & \\
\hline \multirow[t]{3}{*}{ communication } & $\begin{array}{l}\text { Pearson } \\
\text { Correlation }\end{array}$ & $.611^{* * *}$ & $.598^{* *}$ & $.522^{* *}$ & 1 & & \\
\hline & Sig. (2-tailed) & .000 & .001 & .000 & & & \\
\hline & $\mathrm{N}$ & 76 & 76 & 76 & 76 & & \\
\hline \multirow[t]{3}{*}{$\begin{array}{l}\text { effective } \\
\text { systematic plan }\end{array}$} & $\begin{array}{l}\text { Pearson } \\
\text { Correlation }\end{array}$ & $.639^{* * *}$ & $.701^{* *}$ & $.633^{* *}$ & $.528^{* *}$ & 1 & \\
\hline & Sig. (2-tailed) & .000 & .000 & .000 & .000 & & \\
\hline & $\mathrm{N}$ & 76 & 76 & 76 & 76 & 76 & \\
\hline $\begin{array}{l}\text { Strategic } \\
\text { success }\end{array}$ & $\begin{array}{l}\text { Pearson } \\
\text { Correlation }\end{array}$ & $.599^{* * *}$ & $.602^{* *}$ & $.617^{* *}$ & $.697^{* *}$ & $.501^{* *}$ & 1 \\
\hline
\end{tabular}




\begin{tabular}{|l|l|l|l|l|l|l|l|}
\hline & Sig. (2-tailed) & .000 & .000 & .000 & .000 & .000 & \\
\cline { 2 - 7 } & $\mathrm{N}$ & 76 & 76 & 76 & 76 & 76 & 76 \\
\hline
\end{tabular}

As it can be seen in table (3), the correlation analysis between technology change, environment of the change, education, communication, and effective systematic plan), and Strategic success as dependent variable also change management as mediator factor. The finding revealed that the value of Pearson correlation $\left(r=.599^{* *}, \mathrm{p}<0.01\right)$, between technology change and strategic success this indicated that there is positive and strong correlation between technology change and strategic success, the value of Pearson correlation $\left(r=.602^{* *}, \mathrm{p}<0.01\right)$, between environment of the change and strategic success this indicated that there is positive and strong correlation between environment of the change and strategic success, the value of Pearson correlation $\left(r=.617^{* *}, \mathrm{p}<0.01\right)$, between education and strategic success this indicated that there is positive and strong correlation between education and strategic success, the value of Pearson correlation $(r=$ $.697^{* *}, \mathrm{p}<0.01$ ), between communication and strategic success this indicated that there is positive and strong correlation between communication and strategic success, and the value of Pearson correlation $\left(r=.501^{* *}, \mathrm{p}<0.01\right)$, between effective systematic plan and strategic success this indicated that there is positive and strong correlation between effective systematic plan and strategic success.

H1: Change event mediates technology change and Strategic success.

Table 4-Hierarchal Multiple Regression

\begin{tabular}{|c|c|c|c|c|c|c|}
\hline \multicolumn{7}{|c|}{ Coefficients } \\
\hline \multicolumn{2}{|c|}{ Model } & \multicolumn{2}{|c|}{ Unstandardized Coefficients } & \multirow{2}{*}{$\begin{array}{c}\text { Standardized } \\
\text { Coefficients }\end{array}$} & \multirow[t]{2}{*}{$\mathrm{t}$} & \multirow[t]{2}{*}{ Sig. } \\
\hline & & B & Std. Error & & & \\
\hline \multirow[t]{2}{*}{1} & (Constant) & 1.119 & .1221 & & 7.254 & .000 \\
\hline & $\mathrm{CG}$ & .522 & .036 & .529 & 7.362 & .000 \\
\hline \multirow[t]{3}{*}{2} & (Constant) & 1.002 & .214 & & 3.653 & .000 \\
\hline & $\mathrm{CG}$ & .533 & .062 & .537 & 1.622 & .001 \\
\hline & CMI & .558 & .074 & .561 & 3.524 & .000 \\
\hline
\end{tabular}

Table (4), demonstrates a hierarchal multiple regression analysis to investigate first research hypothesis which stated that change management initiative mediates technology change and Strategic success. Concerning model (1) the direct relationship between technology change and strategic success, the value of $B=.522$, the value of Beta $=.529$ with $\mathrm{P}$-value $=.000$ this indicated that there is a significant and positive relationship between technology change and strategic success. As for model (2) which applied multiple regression analysis to find both technology change as independent factor and change eventas a mediator factor with strategic success as dependent factor, the findings showed that the value of $\mathrm{B}=.533$, the value of Beta $=.537$ with P-value .001 as indirect relationship between technology change and strategic success, on the other hand the value of $\mathrm{B}=.558$, the value of Beta $=.561$ with $\mathrm{P}$-value .000 as mediation between change event and strategic success. The findings proved that there is a positive and significant direct and indirect relationship between technology change and strategic success, moreover change event has a positive and significant mediating role between technology change and strategic success. 


\begin{tabular}{|c|c|c|c|c|c|}
\hline & Input: & & Test statistic: & Std. Error: & $p$-value: \\
\hline$a$ & .533 & Sobel test: & 5.66883007 & 0.05246479 & .0002 \\
\hline$b$ & .558 & Aroian test: & 5.64727784 & 0.05266502 & .0003 \\
\hline$s_{a}$ & .062 & Goodman test: & 5.69063094 & 0.0522638 & .0002 \\
\hline & .074 & Reset all & \multicolumn{3}{|c|}{ Calculate } \\
\hline
\end{tabular}

P-value is significant at level 0.005

Table (5), illustrates the findings of Sobel test to find the mediation analysis, the result demonstrates the direct relationship between technology change and strategic success, $\mathrm{P}$-value $=.0002$ this indicated that there is a significant and positive direct relationship between technology change and strategic success. Furthermore, Pvalue is .0003 as indirect relationship between technology change and strategic success. Moreover, the results proved that there is a positive and significant direct and indirect relationship between technology change and strategic success, moreover change event has a positive and significant mediating role between technology change and strategic success.

$\mathrm{H} 2$ : Change event mediates environment of the change and Strategic success.

Table 6: Hierarchal Multiple Regression

\begin{tabular}{|c|c|c|c|c|c|c|}
\hline \multicolumn{7}{|c|}{ Coefficients } \\
\hline \multicolumn{2}{|c|}{ Model } & \multicolumn{2}{|c|}{ Unstandardized Coefficients } & \multirow{2}{*}{$\begin{array}{c}\text { Standardized } \\
\text { Coefficients }\end{array}$} & \multirow[t]{2}{*}{$\mathrm{t}$} & \multirow[t]{2}{*}{ Sig. } \\
\hline & & $\mathrm{B}$ & Std. Error & & & \\
\hline \multirow[t]{2}{*}{1} & (Constant) & 1.011 & .1211 & & 7.985 & .000 \\
\hline & DG & .596 & .039 & .601 & 7.356 & .000 \\
\hline \multirow[t]{3}{*}{2} & (Constant) & 1.002 & .144 & & 3.568 & .000 \\
\hline & DG & .553 & .038 & .559 & 1.574 & .000 \\
\hline & CMI & .601 & .071 & .609 & 3.652 & .000 \\
\hline
\end{tabular}

Table (6), demonstrates a hierarchal multiple regression analysis to investigate second research hypothesis which stated that change management initiative mediates environment of the change and Strategic success. Concerning model (1) the direct relationship between environment of the change and strategic success, the value of $\mathrm{B}=.596$, the value of Beta $=.601$ with $\mathrm{P}$-value $=.000$ this indicated that there is a significant and positive relationship between environment of the change and strategic success. As for model (2) which applied multiple regression analysis to find both environment of the change as independent factor and change eventas a mediator factor with strategic success as dependent factor, the findings showed that the value of $\mathrm{B}=.533$, the value of Beta $=.559$ with $\mathrm{P}$-value .001 as indirect relationship between environment of the change and strategic success, on the other hand the value of $B$ $=.601$, the value of Beta $=.609$ with P-value .000 as mediation between change event and strategic success. The findings proved that there is a positive and significant direct and indirect relationship between environment of the change and strategic success, moreover change event has a positive and significant mediating role between environment of the change and strategic success. 
Table 7: Sobel Test

\begin{tabular}{|c|c|c|c|c|c|}
\hline & Input: & & Test statistic: & Std. Error: & $p$-value: \\
\hline$a$ & .553 & Sobel test: & 7.31700617 & 0.04542199 & 0 \\
\hline$b$ & .601 & Aroian test: & 7.30413234 & 0.04550205 & 0 \\
\hline$s_{\mathrm{a}}$ & .038 & Goodman test: & 7.3299483 & 0.04534179 & 0 \\
\hline$s_{\mathrm{b}}$ & .071 & Reset all & & Calculate & \\
\hline
\end{tabular}

$\mathrm{P}$-value is significant at level 0.005

Table (7), illustrates the findings of Sobel test to find the mediation analysis, the result demonstrates the direct relationship between environment of the change and strategic success, $\mathrm{P}$-value $=.000$ this indicated that there is a significant and positive direct relationship between environment of the change and strategic success. Furthermore, P-value is .000 as indirect relationship between environment of the change and strategic success.
Moreover, the results proved that there is a positive and significant direct and indirect relationship between environment of the change and strategic success, moreover change event has a positive and significant mediating role between environment of the change and strategic success.

H3: Change event mediates education and Strategic success.

Table 8: Hierarchal Multiple Regression

\begin{tabular}{|c|c|c|c|c|c|c|}
\hline \multicolumn{7}{|c|}{ Coefficients } \\
\hline \multicolumn{2}{|c|}{ Model } & \multicolumn{2}{|c|}{ Unstandardized Coefficients } & \multirow{2}{*}{$\begin{array}{c}\text { Standardized } \\
\text { Coefficients }\end{array}$} & \multirow[t]{2}{*}{$\mathrm{t}$} & \multirow[t]{2}{*}{ Sig. } \\
\hline & & B & Std. Error & & & \\
\hline \multirow[t]{2}{*}{1} & (Constant) & 2.191 & .3101 & & 3.258 & .000 \\
\hline & $\mathrm{CA}$ & .611 & .034 & .617 & 4.522 & .000 \\
\hline \multirow[t]{3}{*}{2} & (Constant) & 1.009 & .189 & & 3.588 & .000 \\
\hline & $\mathrm{CA}$ & .622 & .029 & .629 & 1.955 & .000 \\
\hline & CMI & .633 & .071 & .639 & 4.522 & .000 \\
\hline
\end{tabular}

Table (8), demonstrates a hierarchal multiple regression analysis to investigate third research hypothesis which stated that change management initiative mediates education and Strategic success. Concerning model (1) the direct relationship between education and strategic success, the value of $\mathrm{B}=.611$, the value of Beta $=.617$ with P-value $=.000$ this indicated that there is a significant and positive relationship between education and strategic success. As for model (2) which applied multiple regression analysis to find both dur education as independent factor and change eventas a mediator factor with strategic success as dependent factor, the findings showed that the value of $\mathrm{B}$ $=.622$, the value of Beta $=.629$ with P-value .001 as indirect relationship between education and strategic success, on the other hand the value of $\mathrm{B}=.633$, the value of Beta $=.639$ with P-value .000 as mediation between change event and strategic success. The findings proved that there is a positive and significant direct and indirect relationship between education and strategic success, moreover change event has a positive and significant mediating role between education and strategic success. 
Table 9: Sobel Test

\begin{tabular}{|c|c|c|c|c|c|}
\hline \multicolumn{2}{|r|}{ Input: } & & Test statistic: & Std. Error: & $p$-value: \\
\hline$a$ & .622 & Sobel test: & 8.23258392 & 0.04782532 & 0 \\
\hline$b$ & .633 & Aroian test: & 8.22496489 & 0.04786963 & 0 \\
\hline$s_{a}$ & .029 & Goodman test: & 8.24022416 & 0.04778098 & 0 \\
\hline & .071 & Reset all & & Calculate & \\
\hline
\end{tabular}

$\mathrm{P}$-value is significant at level 0.005

Table (9), illustrates the findings of Sobel test to find the mediation analysis, the result demonstrates the direct relationship between education and strategic success, Pvalue $=.000$ this indicated that there is a significant and positive direct relationship between education and strategic success. Furthermore, P-value is .000 as indirect relationship between education and strategic success. Moreover, the results proved that there is a positive and significant direct and indirect relationship between education and strategic success, moreover change event has a positive and significant mediating role between education and strategic success.

H4: Change event mediates communication and Strategic success.

Table 10: Hierarchal Multiple Regression

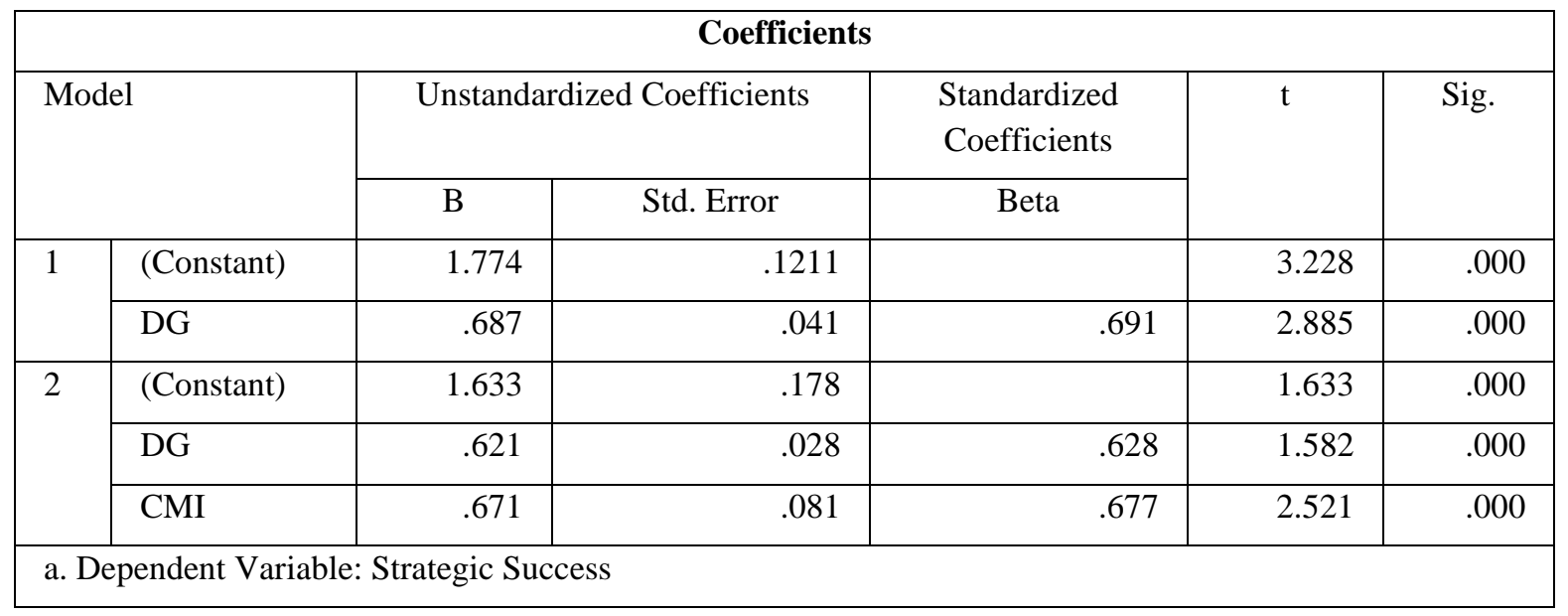

Table (10), demonstrates a hierarchal multiple regression analysis to investigate fourth research hypothesis which stated that change management initiative mediates communication and Strategic success. Concerning model (1) the direct relationship between communication and strategic success, the value of $\mathrm{B}=.687$, the value of Beta $=$ .691 with $\mathrm{P}$-value $=.000$ this indicated that there is a significant and positive relationship between communication and strategic success. As for model (2) which applied multiple regression analysis to find both communication as independent factor and change eventas a mediator factor with strategic success as dependent factor, the findings showed that the value of $B=.621$, the value of Beta $=.628$ with P-value .001 as indirect relationship between communication and strategic success, on the other hand the value of $\mathrm{B}=.671$, the value of Beta $=.677$ with $\mathrm{P}$ value .000 as mediation between change event and strategic success. The findings proved that there is a positive and significant direct and indirect relationship between communication and strategic success, moreover change event has a positive and significant mediating role between communication and strategic success. 
Table 11: Sobel Test

\begin{tabular}{|c|c|c|c|c|c|}
\hline & Input: & & Test statistic: & Std. Error: & $p$-value: \\
\hline$a$ & .621 & Sobel test: & 7.76029581 & 0.05369525 & 0 \\
\hline$b$ & .671 & Aroian test: & 7.75338256 & 0.05374312 & 0 \\
\hline$s_{a}$ & .028 & Goodman test: & 7.76722758 & 0.05364733 & 0 \\
\hline & .081 & Reset all & \multicolumn{3}{|c|}{ Calculate } \\
\hline
\end{tabular}

$\mathrm{P}$-value is significant at level 0.005

Table (11), illustrates the findings of Sobel test to find the mediation analysis, the result demonstrates the direct relationship between communication and strategic success, P-value $=.000$ this indicated that there is a significant and positive direct relationship between communication and strategic success. Furthermore, P-value is .000 as indirect relationship between communication and strategic success. Moreover, the results proved that there is a positive and significant direct and indirect relationship between communication and strategic success, moreover change event has a positive and significant mediating role between communication and strategic success.

H5: Change event mediates effective systematic plan and Strategic success.

Table 12: Hierarchal Multiple Regression

\begin{tabular}{|c|c|c|c|c|c|c|}
\hline \multicolumn{7}{|c|}{ Coefficients } \\
\hline \multicolumn{2}{|c|}{ Model } & \multicolumn{2}{|c|}{ Unstandardized Coefficients } & \multirow{2}{*}{$\begin{array}{c}\begin{array}{c}\text { Standardized } \\
\text { Coefficients }\end{array} \\
\text { Beta }\end{array}$} & \multirow[t]{2}{*}{$\mathrm{t}$} & \multirow[t]{2}{*}{ Sig. } \\
\hline & & B & Std. Error & & & \\
\hline \multirow[t]{2}{*}{1} & (Constant) & 2.711 & .3111 & & 7.885 & .000 \\
\hline & $\mathrm{AC}$ & .528 & .029 & .531 & 7.633 & .000 \\
\hline \multirow[t]{3}{*}{2} & (Constant) & 1.099 & .188 & & 3.652 & .000 \\
\hline & $\mathrm{AC}$ & .539 & .081 & .542 & 3.522 & .000 \\
\hline & CMI & .593 & .072 & .598 & 4.522 & .000 \\
\hline
\end{tabular}

Table (12), demonstrates a hierarchal multiple regression analysis to investigate fifth research hypothesis which stated that change management initiative mediates effective systematic plan and Strategic success. Concerning model (1) the direct relationship between effective systematic plans and strategic success, the value of $\mathrm{B}=.528$, the value of Beta $=.531$ with P-value $=.000$ this indicated that there is a significant and positive relationship between effective systematic plan and strategic success. As for model (2) which applied multiple regression analysis to find both effective systematic plan as independent factor and change eventas a mediator factor with strategic success as dependent factor, the findings showed that the value of $\mathrm{B}$ $=.539$, the value of Beta $=.542$ with $\mathrm{P}$-value .001 as indirect relationship between effective systematic plan and strategic success, on the other hand the value of $\mathrm{B}=.593$, the value of Beta $=.598$ with P-value .000 as mediation between change event and strategic success. The findings proved that there is a positive and significant direct and indirect relationship between effective systematic plan and strategic success, moreover change event has a positive and significant mediating role between effective systematic plan and strategic success. 
Table 13: Sobel Test

\begin{tabular}{|c|c|c|c|c|c|}
\hline & Input: & & Test statistic: & Std. Error: & $p$-value: \\
\hline$a$ & .539 & Sobel test: & 5.1760321 & 0.06175136 & 0 \\
\hline$b$ & .593 & Aroian test: & 5.15310149 & 0.06202614 & 0 \\
\hline$s_{\mathrm{a}}$ & .081 & Goodman test: & 5.19927157 & 0.06147534 & 0 \\
\hline & .072 & Reset all & & Calculate & \\
\hline
\end{tabular}

$\mathrm{P}$-value is significant at level 0.005

Table (13), illustrates the findings of Sobel test to find the mediation analysis, the result demonstrates the direct relationship between effective systematic plan and strategic success, P-value $=.000$ this indicated that there is a significant and positive direct relationship between effective systematic plan and strategic success. Furthermore, P-value is .000 as indirect relationship between effective systematic plan and strategic success. Moreover, the results proved that there is a positive and significant direct and indirect relationship between effective systematic plan and strategic success, moreover change event has a positive and significant mediating role between effective systematic plan and strategic success.

\section{CONCLUSION}

Change is an unavoidable aspect of life. Technology, institutional innovations and processes, internal laws and regulations, the transition of government departments to private companies, organizational restructuring schemes, shifts in management decisions, and other external factors all play a role in different ways. The researchers used multiple regression analysis to assess their established research hypotheses, while the Sobel test was used to determine the function of the mediator, which is the change management initiative. The results showed that all research hypotheses are supported, with the third research hypothesis receiving the highest value, stating that change event mediates education and strategic success, and the first research hypothesis receiving the lowest value, stating that change event mediates technology change and strategic success. Technology transition, the climate of change and strategic success, education, communication and strategic success, and a successful systematic strategy are only a few examples of external factors. Different views and perspectives on change exist in the hospitality industry, which can have both positive and negative consequences. More precisely, successfully managing transformation resistance aided businesses in smoothly implementing change. Organizational transformation helps companies to devise ways to effectively implement change management with the aid of different transition models. Finally, once the transition is in line with the organization's goals and plans, change management provides the company with many benefits.

\section{REFERENCES}

[1] Neves, P., Almeida, P., \& Velez, M. J. (2018). Reducing intentions to resist future change: Combined effects of commitment-based HR practices and ethical leadership. Human Resource Management, 57(1), 249-261.

[2] Luburić, R. (2019). A Model of Crisis Prevention (Based on managing change, quality management and risk management). Journal of Central Banking Theory and Practice, 8(2), 33-49.

[3] Hurtt, G. C., Chini, L., Sahajpal, R., Frolking, S., Bodirsky, B. L., Calvin, K., ... \& Zhang, X. (2020). Harmonization of global land use change and management for the period 850 2100 (LUH2) for CMIP6. Geoscientific Model Development, 13(11), 5425-5464.

[4] Anwar, G., \& Shukur, I. (2015). The Impact of Training and Development on Job Satisfaction: A Case Study of Private Banks in Erbil. International Journal of Social Sciences \& Educational Studies, 2(1), 65.

[5] Neves, P., Almeida, P., \& Velez, M. J. (2018). Reducing intentions to resist future change: Combined effects of commitment-based HR practices and ethical leadership. Human Resource Management, 57(1), 249-261.

[6] Shafiq, M., Zhang, Q., Akbar, M. A., Khan, A. A., Hussain, S., Amin, F. E., ... \& Soofi, A. A. (2018). Effect of project management in requirements engineering and requirements change management processes for global software development. IEEE Access, 6, 25747-25763.

[7] Anwar, K., \& Qadir, G. H. (2017). A Study of the Relationship between Work Engagement and Job Satisfaction in Private Companies in Kurdistan. International Journal of Advanced Engineering, Management and Science, 3(12), 239944.

[8] Alia, B. J. Consumer attitudes towards healthy and organic food in the Kurdistan region of Iraq. Journal of Growing Science, 1-8.

[9] Anwar, K. (2017). Leading Construction Project Teams: The Effectiveness of Transformational Leadership in Dynamic 
Work Environments in Kurdistan. International Journal of Advanced Engineering, Management and Science, 3(10), 239925.

[10] Bousquet, J., Hellings, P. W., Agache, I., Amat, F., AnnesiMaesano, I., Ansotegui, I. J., ... \& Bindslev-Jensen, C. (2019). Allergic Rhinitis and its Impact on Asthma (ARIA) Phase 4 (2018): Change management in allergic rhinitis and asthma multimorbidity using mobile technology. Journal of Allergy and Clinical Immunology, 143(3), 864-879.

[11] Anwar, K., \& Louis, R. (2017). Factors Affecting Students' Anxiety in Language Learning: A Study of Private Universities in Erbil, Kurdistan. International Journal of Social Sciences \& Educational Studies, 4(3), 160.

[12] Ali, B., \& Anwar, G. (2021). The balanced scorecard's evolution as a strategic mechanism at banking sectors. International Journal of English Literature and Social $\quad$ Sciences, $\quad 6(1) ; \quad 471-478$ https://dx.doi.org/10.22161/ijels.61.63

[13] Abdullah, N., \& Anwar, G. (2021). An Empirical Analysis of Natural Gas as an Alternative Fuel for Internal Transportation. International Journal of English Literature and Social Sciences, 6(1) ; 479-485 https://dx.doi.org/10.22161/ijels.61.64

[14] Zheng, P., Chen, C. H., \& Shang, S. (2019). Towards an automatic engineering change management in smart product-service systems-A DSM-based learning approach. Advanced engineering informatics, 39, 203-213.

[15] Ali, B., \& Anwar, G. (2021). The Effect of Marketing Culture Aspects of Healthcare Care on Marketing Creativity. International Journal of English Literature and Social Sciences, $\quad 6(2) ; \quad 171-182$ https://dx.doi.org/10.22161/ijels.62.25

[16] Matthews, J., Love, P. E., Mewburn, J., Stobaus, C., \& Ramanayaka, C. (2018). Building information modelling in construction: insights from collaboration and change management perspectives. Production Planning \& Control, 29(3), 202-216.

[17] Abdullah, N., \& Anwar, G. (2021). Inspiring future entrepreneurs: The effect of experiential learning on the entrepreneurial intention at higher education. International Journal of English Literature and Social Sciences, 6(2) ; 183194 https://dx.doi.org/10.22161/ijels.62.26

[18] Thakur, V., \& Mangla, S. K. (2019). Change management for sustainability: Evaluating the role of human, operational and technological factors in leading Indian firms in home appliances sector. Journal of cleaner production, 213, 847862.

[19] Abdullah, N., \& Anwar, G. (2021). The impact of Human resource management practice on Organizational performance. International journal of Engineering, Business and Management (IJEBM) 5(1) ; 35-47 https://dx.doi.org/10.22161/ijebm.5.1.4

[20] Jayatilleke, S., \& Lai, R. (2018). A systematic review of requirements change management. Information and Software Technology, 93, 163-185.

[21] Ali, B \& Anwar, G. (2021). Factors Influencing the Citizens' Acceptance of Electronic Government. International journal of Engineering, Business and Management (IJEBM) 5(1) ; 48-60 https://dx.doi.org/10.22161/ijebm.5.1.5

[22] Galli, B. J. (2018). Change management models: A comparative analysis and concerns. IEEE Engineering Management Review, 46(3), 124-132.

[23] Abdullah, N., \& Anwar, G. (2021). Global Financial Outlook during the COVID-19 Pandemic: The role of effective leadership styles on Financial outlook. International journal of Engineering, Business and $\begin{array}{llll}\text { Management } & \text { (IJEBM) } & 5(2) \quad \text {; } & \text { 8-20 }\end{array}$ https://dx.doi.org/10.22161/ijebm.5.2.2

[24] Dzwigol, H., Shcherbak, S., Semikina, M., Vinichenko, O., \& Vasiuta, V. (2019). Formation of Strategic Change Management System at an Enterprise. Academy of Strategic Management Journal, 18, 1-8.

[25] Ali, B \& Anwar, G. (2021). An Empirical Study of Employees' Motivation and its Influence Job Satisfaction. International journal of Engineering, Business and Management (IJEBM) 5(2) ; 21-30 : https://dx.doi.org/10.22161/ijebm.5.2.3

[26] Anwar, G., \& Shukur, I. (2015). Job satisfaction and employee turnover intention: A case study of private hospital in Erbil. International Journal of Social Sciences \& Educational Studies, 2(1), 73.

[27] Ali, B. J. (2021). Assessing (The impact) of advertisement on customer decision making: Evidence from an educational institution. Ali, BJ (2021). Assessing (The impact) of advertisement on customer decision making: Evidence from an educational institution. Afak for Science Journal, 6(01), 267-280.

[28] Jones-Schenk, J. (2019). 70\% failure rate: an imperative for better change management. The Journal of Continuing Education in Nursing, 50(4), 148-149.

[29] Anwar, G., \& Shukur, I. (2015). the impact of recruitment and selection on job satisfaction: Evidence from private school in Erbil. International Journal of Social Sciences \& Educational Studies, 1(3), 4-13.

[30] Demir, A., Maroof, L., Khan, N. U. S., \& Ali, B. J. (2020). The role of E-service quality in shaping online meeting platforms: a case study from higher education sector. Journal of Applied Research in Higher Education, 1-28

[31] Anwar, G., \& Abd Zebari, B. (2015). The Relationship between Employee Engagement and Corporate Social Responsibility: A Case Study of Car Dealership in Erbil, Kurdistan. International Journal of Social Sciences \& Educational Studies, 2(2), 45.

[32] Kirrane, M., Lennon, M., O’Connor, C., \& Fu, N. (2017). Linking perceived management support with employees' readiness for change: the mediating role of psychological capital. Journal of Change Management, 17(1), 47-66.

[33] Anwar, G., \& Surarchith, N. K. (2015). Factors Affecting Shoppers' Behavior in Erbil, Kurdistan-Iraq. International Journal of Social Sciences \& Educational Studies, 1(4), 10.

[34] Andavar, V., \& Ali, B. (2020). Rainwater for Water Scarcity Management: An Experience of Woldia University (Ethiopia). ANDAVAR, V., ALI, BJ, \& ALI, SA (2020). Rainwater for Water Scarcity Management: An Experience 
of Woldia University (Ethiopia). The Journal of Business Economics and Environmental Studies, 10(4), 29-34.

[35] Anwar, G., \& Shukur, I. (2015). The Impact of Service Quality Dimensions on Students' Satisfaction. International Journal of Social Sciences \& Educational Studies, 76.

[36] Hussain, S. T., Lei, S., Akram, T., Haider, M. J., Hussain, S. H., \& Ali, M. (2018). Kurt Lewin's change model: A critical review of the role of leadership and employee involvement in organizational change. Journal of Innovation \& Knowledge, 3(3), 123-127.

[37] Anwar, K. (2017). Analyzing the conceptual model of service quality and its relationship with guests'satisfaction: a study of hotels in erbil. The International Journal of Accounting and Business Society, 25(2), 1-16.

[38] Ali, B. J. (2021). Impact of consumer animosity, boycott participation, boycott motivation, and product judgment on purchase readiness or aversion of Kurdish consumers in Iraq. Journal of Consumer Affairs.

[39] Anwar, K. (2016). Comparison between cost leadership and differentiation strategy in agricultural businesses. Custos $\mathrm{E}$ Agronegocio on Line, 12(2), 212-231.

[40] Abdullah, M. S., Toycan, M., \& Anwar, K. (2017). The cost readiness of implementing e-learning. CUSTOS E AGRONEGOCIO ON LINE, 13(2), 156-175.

[41] Anwar, K., \& Balcioglu, H. (2016). The relationship between transformational leadership characteristics and effectiveness: A case study of construction companies in Erbil. International Journal of Science Technology and Management, 5(2), 250-256.

[42] Asadi, S. (2020). Soft systems methodology approach to IS change management. International Journal of Industrial Engineering \& Management Science, 7(1), 84-99.

[43] Anwar, K. (2017). The Role of Effective Leadership in Crisis Management: Study of Private Companies in Kurdistan. Qalaai Zanist Scientific Journal, 2(4), 326-338.

[44] Ali, B. (2020). Impact of COVID-19 on Consumer Buying Behavior Toward Online Shopping in Iraq. Ali, BJ (2020). Impact of COVID-19 on consumer buying behavior toward online shopping in Iraq. Economic Studies Journal, 18(42), 267-280.

[45] Hameed, A. A., \& Anwar, K. (2018). Analyzing the Relationship between Intellectual Capital and Organizational Performance: A Study of Selected Private Banks in Kurdistan. International Journal of Social Sciences \& Educational Studies, 4(4), 39.

[46] Anwar, K., \& Ghafoor, C. (2017). Knowledge management and organizational performance: A study of private universities in Kurdistan. International Journal of Social Sciences \& Educational Studies, 4(2), 53.

[47] Anwar, K., \& Climis, R. (2017). ANALYZING THE RELATIONSHIP BETWEEN TYPES OF ADVERTISEMENT AND CUSTOMER CHOICE: A STUDY OF RETAILER STORES IN ERBIL. The International Journal of Accounting and Business Society, 25(2), 43-52.

[48] Brones, F. A., de Carvalho, M. M., \& de Senzi Zancul, E. (2017). Reviews, action and learning on change management for ecodesign transition. Journal of Cleaner Production, 142, 8-22.

[49] Anwar, K. (2017). Factors Affecting Stock Exchange Investment In Kurdistan. The International Journal of Accounting and Business Society, 25(1), 32-37. 